\title{
QUALITY ASSESSMENT OF NONFERROUS METALS RECOVERED BY MEANS OF LANDFILL MINING: A CASE STUDY IN BELGIUM
}

\author{
Hugo Ignacio Lucas ${ }^{1, *}$, Cristina García López ${ }^{2}$, Juan Carlos Hernández Parrodi ${ }^{3,4}$, Daniel \\ Vollprecht ${ }^{3}$, Karoline Raulf ${ }^{2}$, Roland Pomberger ${ }^{3}$, Thomas Pretz ${ }^{2}$ and Bernd Friedrich ${ }^{1}$
}

${ }^{1}$ IME - Process Metallurgy and Metal Recycling, RWTH Aachen University, Germany

2 IAR - Department of Processing and Recycling, RWTH Aachen University, Germany

${ }^{3}$ AVAW - Chair of Waste Processing Technology and Waste Management, Montanuniversität Leoben, Austria

${ }^{4}$ Renewi Belgium SA/NV, NEW-MINE project, Belgium

Article Info:
Received:
1 July 2019
Revised:
9 December 2019
Accepted:
18 December 2019
Available online:
23 December 2019
Keywords:
Landfill mining
Nonferrous metals
Recovery
Recycling
Assessment
Defilement
Scrap market

\section{INTRODUCTION}

NFMs such as $\mathrm{Cu}, \mathrm{Al}, \mathrm{Zn}, \mathrm{Pb}, \mathrm{Cr}, \mathrm{Ni}, \mathrm{Ag}$ and $\mathrm{Au}$, are distinguished from ferrous metals (FMs) based on their low or zero magnetization when in the proximity of a magnetic field. NFMs are perhaps the most valuable secondary raw material found in several types of waste, including electronic waste, construction and demolition (C\&D) waste, industrial waste, and municipal solid waste (MSW). Many NFMs are considered strategic metals in Europe (Roadmap to a Resource Efficient Europe) and used in countless applications. Accordingly, the European Commission has prioritised sustainable access to critical raw materials through the recycling and reuse of waste.

In the field of NFM sorting, eddy current separators (ECSs), dense media separators (Barker, 2014) and hand sorting (Capuzzi and Timelli, 2018) are commonly em- ployed. Furthermore, sorting technologies have been developed to automate and optimise the sorting processes: $\mathrm{X}$-ray fluorescence (XRF), colour sorting and X-ray tomography (XRT) can be used for different qualities of $\mathrm{Cu}, \mathrm{Al}$, $\mathrm{Pb}, \mathrm{Zn}$ and stainless steel scrap (Dürkoop et al., 2016; Schlesinger, 2013; Schlesinger et al., 2011).

The valorisation of scraps from non-conventional sources such as, for instance, MSW, C\&D, or even landfilled waste (LFW) indicates the need for a detailed understanding of both the concentration and quality of the metals and the number of steps or techniques applied to separate the latter into different metal categories and grades. For example, Soo et al. (2019) investigated the influence of different sources of Al-scraps from an aluminium recycling facility in Belgium demonstrating how the quality obtained was linked to particle size and metal source. 
Several authors have highlighted the accumulation over time in a large number of landfills of a vast quantity of materials, which might be suitable for use as potential secondary resources (Kapur and Graedel, 2006; Lifset et al., 2002; Muller et al., 2006; Quaghebeur et al., 2013). For example, according to Krook et al. (2012), the amount of Cu landfilled worldwide is comparable to the existing stock in use within the technosphere. Likewise, Cohen-Rosenthal (2004) reported an amount of Al and steel stored in a site investigated corresponding to approx. 1,000 tons and 12,000 tons, respectively, per excavated hectare.

According to Winterstetter et al. (2015), and Van Vossen and Prent (2011), in addition to the most common economic drivers such as reclaimed land or avoidance of repeated landfilling costs, NFMs contribute extensively to the revenues of LFM. However, metals remain buried for several decades, potentially subjected to corrosion and pollution before being excavated from a landfill. There is a clear lack of information in the literature relating to metal concentration, quality and marketability of these scraps. Table 1 illustrates the number of metals found in several LFM projects, not all of which indicated the proportion of FMs and NFMs; indeed, only the Austrian LAMIS project indicated the actual concentration of the ferrous fraction obtained by mechanical processing after a pyrometallurgical trial using an induction furnace (Wolfsberger et al., 2015).

Therefore, the main research questions addressed by this study are:

- What is the actual concentration of NFMs, and what is the extent of surface defilements ?

- Can the recovered NFMs be commercialised and, if so, under what standard?

\section{MATERIALS AND METHODS}

\subsection{Site description}

NFMs analysed in this study were excavated from a landfill site located in the municipality of Mont-Saint-Guibert (MSG) in the province of Walloon Brabant, Belgium (Figure 1). This site covers an area of approx. 44 ha, which has been in operation since 1937 as a sand quarry and was transformed in 1958 into a disposal site for MSW, C\&D waste and non-hazardous industrial waste (ISSeP, 2011). The excavation took place in the oldest part (red delimited area in Figure 1a) which covers a surface of 14 ha, storing circa 5.7 million $\mathrm{m}^{3}$ of waste (Hernández Parrodi et al., 2019; IGRETEC, 1994).

For the purpose of this study, a small zone of circa 130 $\mathrm{m}^{2}$ from the old part of the landfill (white delimited area in Figure 1b) was selected for excavation based on the results of the geophysical exploration (García López et al., 2018; Hernández Parrodi et al., 2019a).

\subsection{Excavation works and material pre-processing}

The selected area was excavated to a depth of approx. $5 \mathrm{~m}$ (excluding $4 \mathrm{~m}$ of cover layer) and roughly 370 ton of LFW extracted (Figure 2a). The excavated volume $\left(425 \mathrm{~m}^{3}\right)$ was divided into four sub-volumes (batches 1-4) of $140 \mathrm{~m}^{3}$, $100 \mathrm{~m}^{3}, 120 \mathrm{~m}^{3}$ and $65 \mathrm{~m}^{3}$, respectively. The batches were classified in situ according to type of waste. Batches 1 and 2 were mainly composed of MSW and C\&D, while batch 3 was largely comprised of C\&D and batch $4 \mathrm{MSW}$. These batches had previously been processed using a ballistic separator (Figure $2 b$ ) in two steps, producing three different outputs: 3D, 2D and under-screen fractions. In the first step, the ballistic separator used a screen of $200 \mathrm{~mm}$, while

TABLE 1: Concentration of metals in previous LFM investigations (Hernández Parrodi et al., 2018).

\begin{tabular}{|c|c|c|c|c|c|c|c|}
\hline Bibliography & $\begin{array}{l}\text { Van Vossen and } \\
\text { Prent, 2011 } \\
\text { (various } \\
\text { countries) }\end{array}$ & $\begin{array}{l}\text { Kaartinen et al., } \\
2013 \text { (Kuopio, } \\
\text { Finland) }\end{array}$ & $\begin{array}{l}\text { Quaghebeur et } \\
\text { al., } 2013 \text { (REMO, } \\
\text { Belgium) }\end{array}$ & $\begin{array}{l}\text { Wolfsberger et } \\
\text { al., } 2015 \text { (Lower } \\
\text { Austria, Austria) }\end{array}$ & $\begin{array}{c}\text { Jani et al., } 2016 \\
\text { (Högbytorp, } \\
\text { Sweden) }\end{array}$ & $\begin{array}{c}\text { Bhatnagar et al., } \\
2017 \text { (Kudjape, } \\
\text { Estonia) }\end{array}$ & $\begin{array}{c}\text { Garcia Lopez et } \\
\text { al. } 2018 \text { (MSG, } \\
\text { Belgium) }\end{array}$ \\
\hline $\begin{array}{l}\text { Type of waste } \\
\text { disposed }\end{array}$ & Various & MSW & MSW & MSW & $M S W+C \& D$ & MSW & $\begin{array}{c}\text { MSW+ } \\
\text { C\&D }\end{array}$ \\
\hline Total metals & $2.0 \%$ & $3.0-4.0 \%$ & $2.8 \pm 1.0 \%$ & $2.1-4.7 \%$ & $1.0 \%$ & $3.1 \%$ & $2.9 \%$ \\
\hline
\end{tabular}
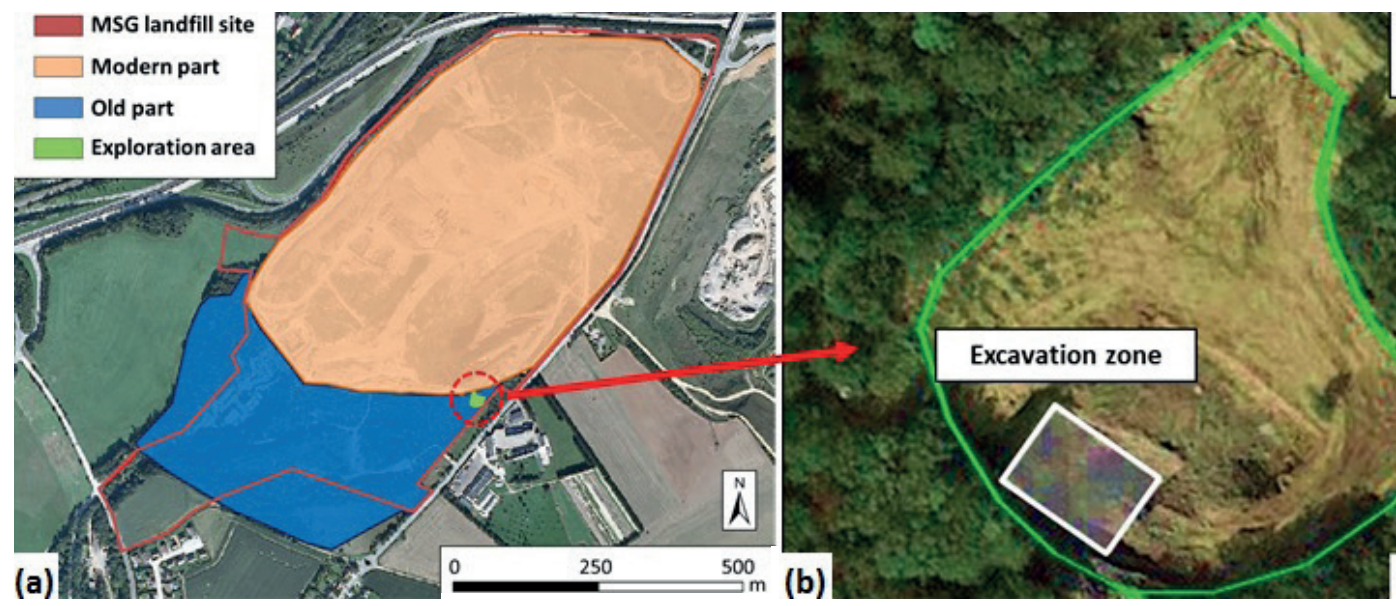

Exploration area (NEW-MINE Project)

FIGURE 1: MSG landfill (a) and excavation zone (b) (Hernández Parrodi et al., 2019a). 

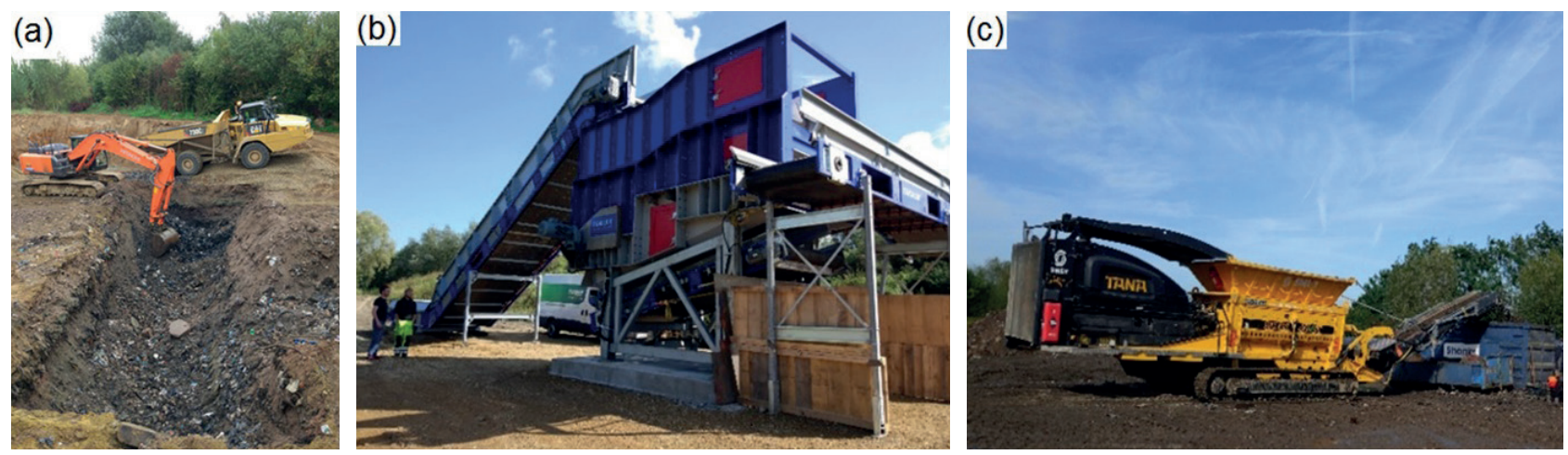

FIGURE 2: (a) Excavator and dumpster; (b) ballistic separator; (c) mobile shredder.

the second step was performed with a screen of $90 \mathrm{~mm}$.

The under-screen fraction below $90 \mathrm{~mm}$ was defined as the fine fraction, whereas materials with a particle size $\geq 90 \mathrm{~mm}(3 \mathrm{D} \geq 200 \mathrm{~mm}, 2 \mathrm{D} \geq 200 \mathrm{~mm}, 3 \mathrm{D} 200-90 \mathrm{~mm}$ and 2D 200-90) corresponded to the coarse fraction. The $2 \mathrm{D}$ fraction from the first step of the ballistic separation ( $\geq 200 \mathrm{~mm}$ ) was processed in situ using a mobile shredder equipped with a built-in over-belt magnetic separator (Figure 2c) to recover FMs. The rest of the material was sampled and subsequently processed. Further information about this landfill site and the characteristics of the excavated material can be found in García López et al., 2019, and Hernández Parrodi et al., 2019a.

\subsection{Material processing}

During the excavation, samples were obtained as prescribed by the German Directives LAGA-PN78 and LAGAPN98. With the exception of the $3 D$ fraction $\geq 200 \mathrm{~mm}$, manually sorted in situ, the remaining fractions were first dried at $75^{\circ} \mathrm{C}$ (based on DIN CEN/TS $15414-1$ to prevent loss of volatile matter and degradation of certain plastics) and then processed at the Department of Processing and Recycling (IAR) of RWTH Aachen University. Table 2 summarises the sampling of different fractions. A detailed description of the methodology and material composition can be found in García López et al. 2019 and Hernandez Parrodi et al., 2019b.

Different methods of metal extraction were chosen according to particle size. NFMs in the coarse fractions (200$90 \mathrm{~mm}$ and $\geq 200 \mathrm{~mm}$ ) were retrieved manually following the recovery of FM using different types of magnetic separators. On the other hand, the fine fraction $(<90 \mathrm{~mm})$ was

TABLE 2: List of processed samples.

\begin{tabular}{|c|c|c|c|}
\hline Fraction & $\mathrm{N}^{\circ}$ of samples & $\begin{array}{c}\text { Mass } \\
\text { processed [kg] }\end{array}$ & $\begin{array}{l}\text { Batches } \\
\text { analysed }\end{array}$ \\
\hline $3 \mathrm{D} \geq 200 \mathrm{~mm}$ & \multicolumn{3}{|c|}{ Processed in-situ } \\
\hline $2 \mathrm{D} \geq 200 \mathrm{~mm}$ * & 30 & 413 & $1,2,3 \& 4$ \\
\hline 2D 200-90 mm & 21 & 474 & $1,2,3$ \\
\hline 3D 200-90 mm & 23 & 203 & $1,2,3$ \\
\hline$<90 \mathrm{~mm}$ & 16 & 200 & $1 \& 2$ \\
\hline
\end{tabular}

* Note: fraction shredded down to $275 \mathrm{~mm}$ subdivided into three particle size ranges, i.e. $90-30 \mathrm{~mm}$, 30-10 $\mathrm{mm}$ and 10-4.5 $\mathrm{mm}$ to enhance the recovery of FMs and NFMs using magnetic separators (over band and drum magnetic) and ECSs, respectively. The fraction $<4.5 \mathrm{~mm}$ was not processed further for recovery of FMs and NFMs. Further details regarding the mechanical processing of fine fractions are reported in Hernández Parrodi et al. 2019b.

NFMs from both coarse and fine fractions were separated further by manual sorting and divided into different categories: non-magnetic Fe scrap, Cu scrap, Al scrap, heavy scrap and unknown metals.

Following this preliminary separation, a portable XRF analyser (Thermo Fisher NITON XL3t 600) and a digital balance were used to analyse the chemical composition and weigh each metallic particle respectively in order to perform a quantitative analysis.

On average, almost 240 different metallic pieces were analysed, of which $74 \mathrm{wt} \%$ originated from the fine fractions. Based on their chemical composition and morphology, metal particles were organised into the categories listed in Table 3.

Figure 3 summarises the characterisation process carried out in this study from the excavation and mechanical processing outputs to the assessment of metallic scraps.

\subsection{Assessment of metal quality}

To assess defilements bound to NFMs and actual metal concentration, three different approaches were tested. The first method was based on ultrasonic cleaning as most of the impurities remained attached to the metals after cleaning for 20 minutes. The second approach was the same method used in the Austrian LAMIS Project (Wolfsberger et al., 2015) based on the smelting of scraps in a raw state. Smelting provides a detailed insight into the metal grade and alloy content, although providing only a rough estimation of defilements, as was the case with Al scrap recovered from MSG (Lucas et al., 2019). For example, Al has a high affinity for oxygen, and during smelting and casting lost around $50 \%$ of its mass as a result of oxidation (Samuel, 2003).

Carbon-rich defilements may act as reductants of metal oxides or favour the formation of carbides during smelting of different NFMs, which in many cases is critical and undesired. As an example, metal oxides such as Ti (i.e. from 
TABLE 3: Classification of metal categories from NFM samples of MSG landfill.

\begin{tabular}{|c|c|}
\hline Category name & Details \\
\hline Al-foils & Foils of aluminium usually used for food preparation \\
\hline Al-packaging & Used beverage cans (UBC), Tetrapack@ and other aluminium packaging such as aerosol cans, aluminium wrapping, etc. \\
\hline Al-alloy & Remaining aluminium particles found in waste, not included in Al-foils and Al-packaging \\
\hline Brass & Metallic particles mainly composed of $\mathrm{Cu}$ and $\mathrm{Zn}$ \\
\hline Cu-wires & Electric wires \\
\hline Pb-alloy & Metallic particles in which $\mathrm{Pb}$ was the main element \\
\hline Stainless steel & Nonmagnetic Fe-scrap containing elements such as $\mathrm{Cr}$ and $\mathrm{Ni}$ \\
\hline Zn-alloy & Metallic particles in which Zn was the main element \\
\hline Other metals & Rest of the metals found with a low frequency such as bronzes, silver alloys, iron scraps (mainly Fe-Sn food cans), nickel alloys, etc. \\
\hline
\end{tabular}

the coating of Al cans), Fe, Si, Zn, found in a vast number of natural minerals and soils can be easily reduced by Al during smelting and end up in the metallic phase as alloying (Schlesinger, 2013; Schmitz et al., 2006)

Finally, the best results were obtained using thermal treatment based on the de-coating process used by the Al industry in the treatment of used beverage cans (UBC) prior to smelting (Schmitz, 2006; XIAO et al., 2005). Al is potentially the NFM most heavily affected by thermal treatment due to its high affinity for oxygen. Indeed, literature reports

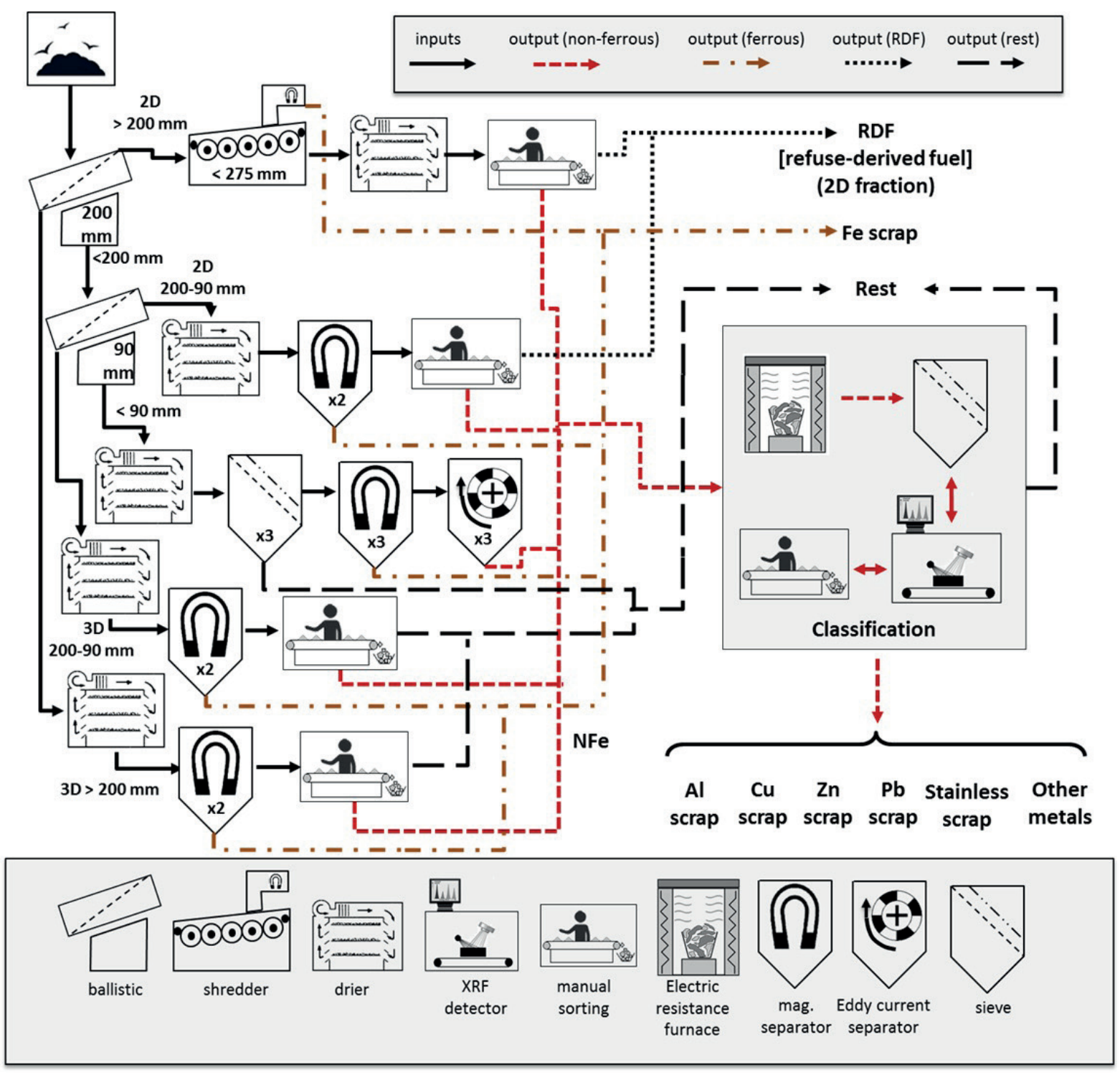

FIGURE 3: Scheme of NFM processing of excavated LFW. 
recommend temperatures ranging between $400-450^{\circ} \mathrm{C}$ to minimise metal losses during this step (Schmitz et al., 2006). The treatment temperatures applied to NFMs were invariably below boiling point, with $\mathrm{Al}, \mathrm{Fe}, \mathrm{Cu}$ and other less common scraps, for instance, $\mathrm{Ni}$ or Ag, remaining unmolten during treatment. In addition to $\mathrm{Al}$, the most critical scraps were those compounded mainly by $\mathrm{Pb}$ and $\mathrm{Zn}$, which are liquid at $450^{\circ} \mathrm{C}$. These materials, smelted separately, showed no critical degradation during treatment. With regard to other possible volatile compounds such as water or salt, scraps had previously been dried during the material processing, and as the melting point for the majority of salts is above $750^{\circ} \mathrm{C}$, these compounds were not expected to volatilise during thermal treatment.

For the reasons stated above, the scraps listed in Table 3 were treated at $400 / 450^{\circ} \mathrm{C}$ for $30 \mathrm{~min}$ in an air atmosphere using an electric resistance furnace. A thermocouple type $\mathrm{K}$ placed inside the crucible guaranteed temperature control.

Scraps incinerated inside 0.4 litre-clay crucibles were weighed before and after thermal treatment using a high precision balance. Weight loss registered between the input and output of each incinerated scrap category was interpreted as the organic content. Following thermal treatment, outputs were sieved at $1 \mathrm{~mm}$, washed and finally dried at $100^{\circ} \mathrm{C}$ for 24 hours. Large non-metallic particles such as rock, ceramics or glass were removed by hand. The weight difference between incineration output and cleaned metals was taken as inorganic content.

With regard to the marketability of metal scraps, it should be highlighted how industry standards are used as references in scrap trading. Several of these standards and their denomination codes are summarised in the Scrap Specifications Circular which is updated every year. However, no specific denomination has been coined for unconventional sources of mixed nonferrous scraps such as those originating from MSW or LFW. Hence, prices are subject to agreement between buyers and sellers, and essential aspects such as the variety of metals contained in the scraps, and the concentration and nature of defilement should be given due consideration, particularly as the number of separation steps and final destination of these metals are heavily dependent on the latter. For example, Soo et al. (2019) studied the influence of different Al fractions recovered from a Belgian recycling facility. In this study, fractions $<12 \mathrm{~mm}$ and $\geq 40 \mathrm{~mm}$ exhibited a large number of undesired alloys (Fe, Cu, Zn, Si, among others) after smelting; moreover, a particular fraction mixed with $\mathrm{Fe}$ scrap was separated manually, increasing not only operative costs but also producing low Al grades with a marginal profit.

To date, the market is devoid of reference standards for scraps recovered from landfills. Using information collected from incineration outputs, seven potential marketable scraps that adhered closely to the standards applied in the scrap market were defined and are listed in Table 4.

Further to dividing NFMs into a series of different scrap categories, metal concentration should also be taken into account in order to estimate the potential value. In this study, the price of each scrap category $\left(P_{\text {scrap }}^{\text {landl }}\right)$ extracted from landfill was defined as the product between the price of the closed standard scrap $\left(P_{\text {scrap }}^{\text {stand }}\right)$ listed in Table 5, divided by its concentration of metals ( $M^{\text {standard }}$ pre-established in the Scrap Specifications Circular), and multiplied by the metal concentration of each pre-defined category $\left(M^{\text {landfill }}\right)$. This methodology is summarised in equation 1.

$P_{\text {scrap }}^{\text {landfill }}=P_{\text {scrap }}^{\text {standard }} \times M^{\text {standard }} / M^{\text {landfill }}$

\section{RESULTS}

\subsection{Mechanical processing and manual sorting}

Manual and mechanical sorting of ballistic separation output fractions revealed that metals represented $2.9 \mathrm{wt} \%$ of input material, with NFMs constituting only $16.5 \%$.

Notably, the distribution of metals across particle size was largely similar to the distribution registered for input material (see Table 6), i.e. no particular abundance of metals across any of the particle size fractions.

Figures $4 \mathrm{a}$ and $4 \mathrm{~b}$ illustrate the results obtained for NFMs classified according to the category of metals detected most frequently from fine and coarse fractions, respectively.

The category "Others" includes minor and less common scraps such as bronze, steel-tin cans, Ni scraps and the considerably less common Ag scraps (silverware). All these scraps together represented less than $1.9 \mathrm{wt} \%$ of total NFM fraction.

TABLE 4: Categories of potentially marketable NFM scraps.

\begin{tabular}{|c|c|}
\hline Category name & Details \\
\hline \multicolumn{2}{|l|}{ Al-scrap } \\
\hline Al-scrap I & High grade: fraction $10-90 \mathrm{~mm}$ and which is mainly composed of UBC and to a lesser extent Al-foils. \\
\hline Al-scrap II & Low grade: rest of Al scraps. \\
\hline \multicolumn{2}{|l|}{ Cu-scrap } \\
\hline Cu-scrap I & High grade: the category Cu-wires from the fraction $\geq 90 \mathrm{~mm}$ \\
\hline Cu-scrap II & Low grade: rest of NFMs, except Zn, Pb and stainless-steel scraps \\
\hline Pb-scrap & Mixed Pb scrap \\
\hline Zn-scrap & Mixed Zn scrap \\
\hline Stainless-steel scrap & Mixed stainless steel scrap \\
\hline
\end{tabular}


TABLE 5: Prices of nonferrous scrap in Jun 2019.

\begin{tabular}{|c|c|c|}
\hline ISRI code & Category & Price (euro/ton) \\
\hline SCORE & Zn mixed scrap & 600 \\
\hline SABOT & $18 / 8$ stainless steel solids & 720 \\
\hline RACKS/RADIO & Pb soft scrap & 1,100 \\
\hline NA & Pb scrap & 1,000 \\
\hline RAINS & $\mathrm{Pb}$ scrap from auto batteries & 820 \\
\hline BERRY & Dry bright wire & 4,000 \\
\hline CANDY & Copper Wire and Tubing Scrap & 3,450 \\
\hline DRUID & Insulated Cu wire ( $85 \%$ recovered scrap) & 1,900 \\
\hline $\mathrm{BIRCH}$ & Copper wire $\mathrm{N}^{0} 2$ with a metal purity $>96 \%$ & 3,250 \\
\hline ZEBRA & Mixed brass & 2,400 \\
\hline NA & Heavy brass & 2,400 \\
\hline ZORBA & Zorba90 (90\% of NFMs) & 500 \\
\hline DROID & Insulated copper wire № 2 with a metal purity $>96 \%$ ( $45 \%$ recovered scrap) & 1,100 \\
\hline TAKE, TALC, TALCRED & UBC & 1,400 \\
\hline TAINT/TABOR & Aluminium foil & 200 \\
\hline
\end{tabular}

Source: www.recycling.com; www.scrapmonster.com

Cu and Al scraps represented approx. 80\% of NFMs recovered from this landfill. Al scraps, mainly present as foils and packaging, were the most common metals found in the fine fraction (44.5 wt\%) followed by Cu scraps (Brass and Cu-wires) (33.4 wt\%). In the coarse fraction, Cu scraps were the most widely detected NFMs with $50.2 \mathrm{wt} \%$.

$\mathrm{Pb}$ and $\mathrm{Zn}$ scraps were mainly detected in fine fractions; $\mathrm{Pb}$ scraps originate from a series of sources, including automotive battery parts, old plumbing, and roof covers, among other unknown sources, whilst $\mathrm{Zn}$ is mainly used as anticorrosive layers in Fe scraps and as an alloy in $\mathrm{Cu}$. However, Zn scraps within NFMs were also found frequently as mechanical components or in alkaline batteries.

Stainless steel scraps were recovered largely from the coarse fraction by hand-sorting, whilst ECSs retrieved only small amounts in the fine fraction. The fine fraction may however contain more stainless steel than the quantities retrieved. The lift-off for stainless steel in ECSs is the lowest of all NFMs (76 times lower than Al), with small pieces tending to remain in the waste when impurities have adhered to the scraps (AbdAlla et al., 2019; Kristian Kahle, Ramboll et al., 2015; Spencer and Schlömann, 1975).

\subsection{Thermal processing}

Figures 5 and 6 summarise the results obtained from the thermal processing and chemical analysis of each metal sample.

TABLE 6: Mass distribution of LFW processed with ballistic separators.

\begin{tabular}{l|cccc}
$\begin{array}{l}\text { Screening } \\
\text { results [wt\%] }\end{array}$ & $\begin{array}{c}\text { Input } \\
\text { material }\end{array}$ & $\begin{array}{c}\text { Ferrous } \\
\text { (2.39 wt\% } \\
\text { input) }\end{array}$ & $\begin{array}{c}\text { Non-ferrous } \\
\text { (0.47 wt\% } \\
\text { input) }\end{array}$ \\
\hline$\geq 200 \mathrm{~mm}$ & $6 \%$ & $8 \%$ & $8 \%$ \\
\hline $200-90 \mathrm{~mm}$ & $16 \%$ & $24 \%$ & $18 \%$ \\
\hline$<90 \mathrm{~mm}$ & $78 \%$ & $68 \%$ & $74 \%$ \\
\hline
\end{tabular}

In general, the fine fractions contained more impurities than coarse fractions (Figure 7). Large metallic particles, largely from the category of C\&D waste, did not contain more than $15 \mathrm{wt} \%$ of defilements (see all categories in Figure. $5 \mathrm{~b}$, with the exception of Al-foils and Al-pack). The only exception was Cu-wires, for which polymeric insulating cover accounted for almost $50 \mathrm{wt} \%$.

With the exception of categories Al-foils, Al-pack and other metals which contained degraded biological matter, the remaining burnable defilements were mostly polymers and carton used in association with various metals.

The chemical compositions presented in Figures $6 \mathrm{a}$ and $6 \mathrm{~b}$ reveal how the two main fractions analysed $(<90 \mathrm{~mm}$ and $\geq 90 \mathrm{~mm}$ ) displayed similar ratios of defilements (circa $30 \mathrm{wt} \%$ ). In contrast, the proportion of NFMs differed, with Al representing the most widely present traditional metal in the fine fraction, followed by e.g. Cu and $\mathrm{Zn}$, both of which commonly found in MSW (Morf et al., 2013).

Contrary to expectations, the typical chemical composition of scraps from the coarse fraction (originating largely from C\&D waste) was dominated by Cu (34.1 wt\%), followed by $\mathrm{Al}$ (15.6 wt\%), rather than vice versa. The important chemical elements $\mathrm{Fe}, \mathrm{Ni}$ and $\mathrm{Cr}$ were also detected due to the presence of stainless steel.

\subsection{Assessing the marketability of NFMs}

Assessment of the marketability of scraps based on the results obtained by mechanical separation may lead to an inaccurate conclusion as to the potential profitability of these recovered metals. One clear example is represented by $\mathrm{Cu}$. In the coarse fraction, the most frequently detected scrap was Cu-wires (39.2 wt\%) (see Cu-wires in Figure 3b). However, when applied to this category, thermal treatment revealed a metal concentration of only $47.8 \mathrm{wt} \%$ (see Cuwires in Figure $5 b$ ), thus indicating a lower concentration of actual $\mathrm{Cu}$ in the coarse fraction. 
(a)

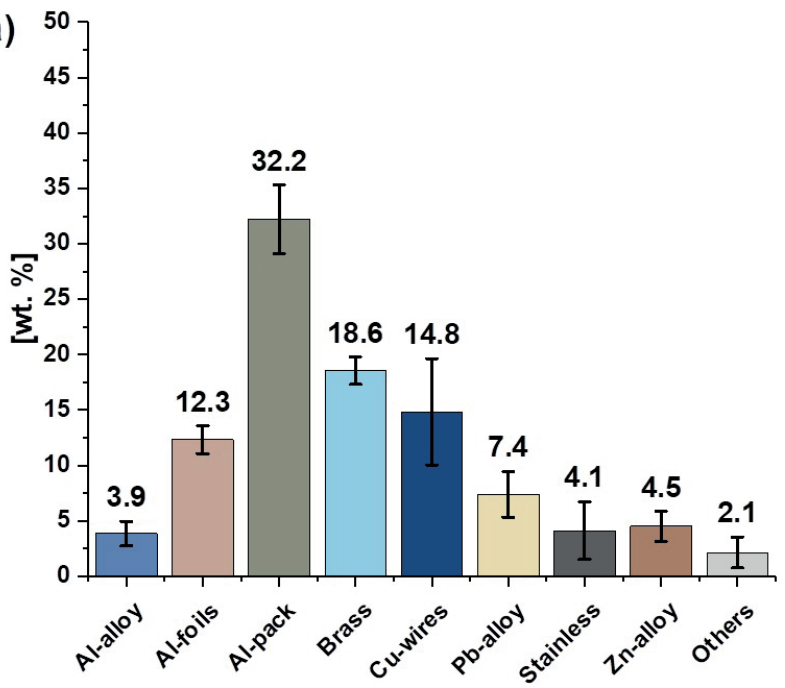

(b)

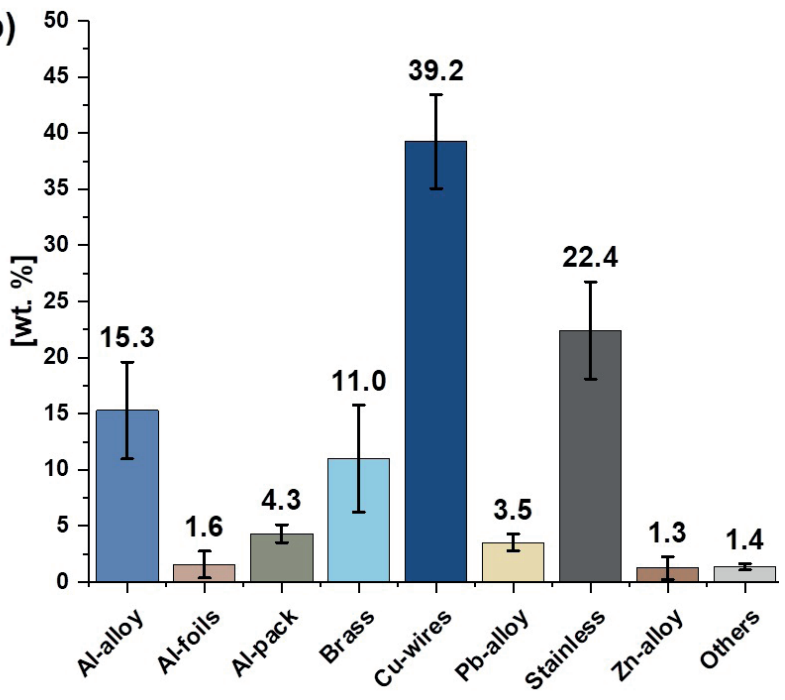

FIGURE 4: Categories of NFMs after mechanical separation [wt\%]: (a) fine fractions ( $<90 \mathrm{~mm})$, (b) coarse fractions ( $\geq 90 \mathrm{~mm})$.

\subsubsection{Metal concentration and surface defilements}

To focus on the first question asked at the start of this paper, relating to metal concentration and surface defilements in NFMs, the results obtained by thermal treatment indicated the presence of approx. $27.3 \mathrm{wt} \%$ defilements (Figure 6c), of which 20.8 wt\% organic (burnable) and 6.5 wt\% inorganic. Both fine and coarse fractions displayed similar trends of defilements (see Figures $6 a$ and $6 b$ ). Nevertheless, defilements in fine sub-fractions $(4.5-10 \mathrm{~mm}$ .10-30 $\mathrm{mm}$ and 30-90 $\mathrm{mm}$ ) showed significant discrepancies, in particular the fraction 4.5-10 mm with impurities amounting to approx. 40-50 wt\% (Figure 7).

The origin of these impurities however varied. Defilements in the fine fraction were related to landfilled MSW in which polymers present in packaging and decomposed organic matter in contact with soil material had become bound to the metals over the years.

On the other hand, in the coarse fraction, organics were represented mainly by polymers which had formed composites with metals such as Cu-wires, with a polymeric fraction of roughly $41 \mathrm{wt} \%$. Residual soil materials agglomerated on the metal surface represented the main source of inorganic defilements. Glass and ceramics used in electrical applications, such as switches, fusible plugs, and light bulb holders, among other materials, were detected bound to several metals.

The concentration of metals ranged from $56.5 \mathrm{wt} \%$ in the fraction $4.5-10 \mathrm{~mm}$ to 74.1 in the fractions $\geq 90 \mathrm{~mm}$ (Figure 7). The fraction 30-90 mm yielded the highest number of metals, driven by Al packaging such as UBC, Al foils and different types of Cu alloys.

\subsubsection{Marketable scraps}

To answer the last question raised, relating to the commercialisation of the scraps identified, two approaches were used in order to assist decision-makers during the (a)

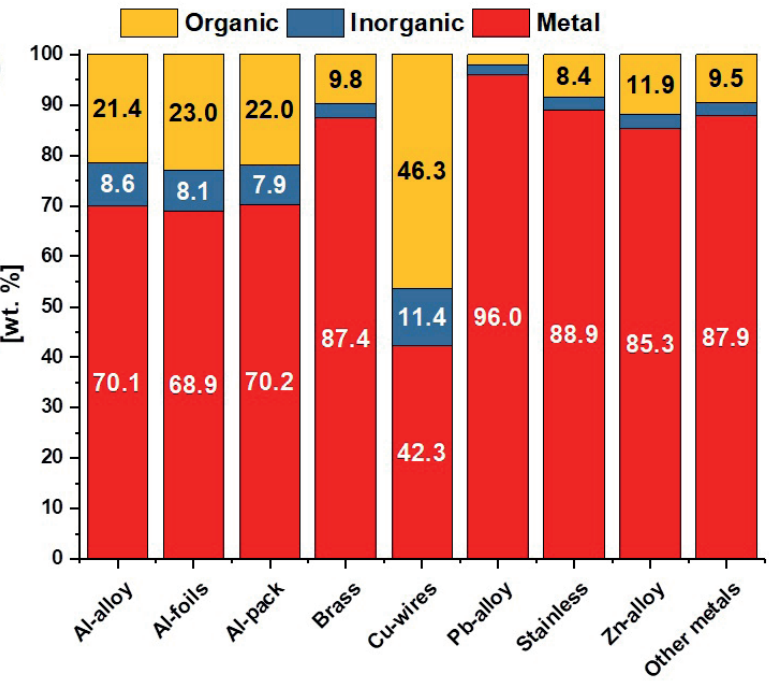

(b)

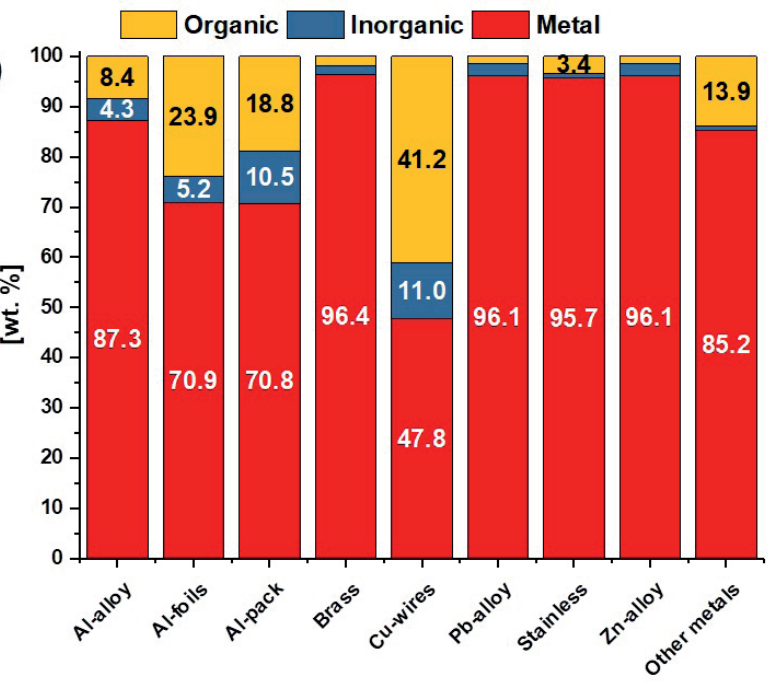

FIGURE 5: Concentration of metal, organic and inorganic matter present in each NFM [wt\%]: (a) fine fractions ( $<90$ mm), (b) coarse fractions $(\geq 90 \mathrm{~mm})$. 

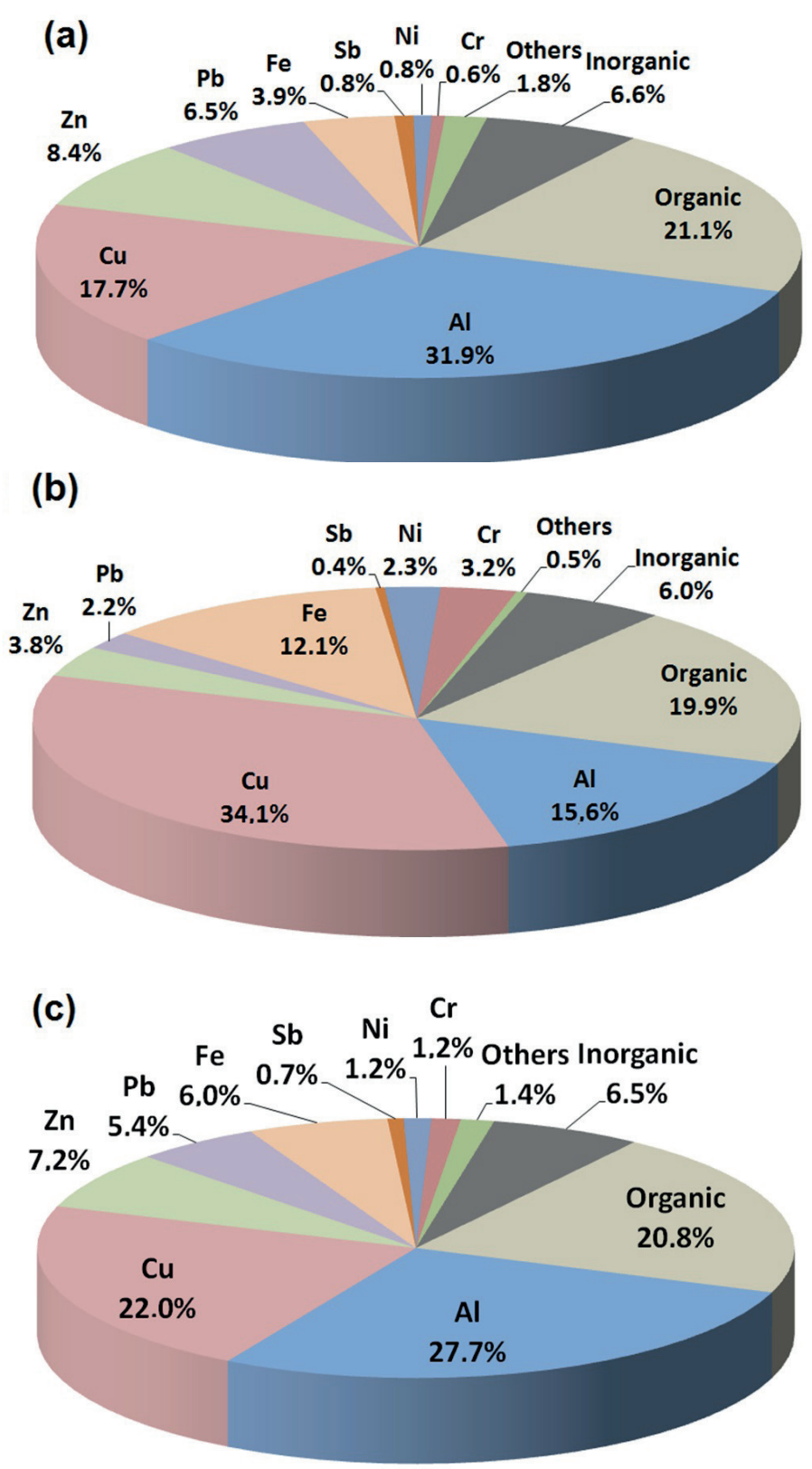

FIGURE 6: Chemical composition of NFMs: (a) fine fractions ( $<90 \mathrm{~mm})$, (b) coarse fractions ( $\geq 90 \mathrm{~mm})$, and (c) global composition.

assessment of upcoming LFM projects.

During the excavation and treatment of LFW in situ, magnetic separators and ECSs may be installed for use in metal separation. On applying these technologies, the extracted NFMs would then be suitable for marketing as a mixed nonferrous scrap. In the presence of Al as the majority metal contained in NFMs, as was the case in the present study, NFMs are traded under the standard identified as Zorba (Scrap Specifications Circular, 2017). This scrap category also requires the addition of two numbers affirming metal concentration.

The price of Zorba90 (90 refers to $90 \%$ metal concentration), typically detected in C\&D and MSW, is in the range of 500 euros per ton (Table 5). Within the framework of the analysis carried out here, NFMs from MSG was defined as Zorba70, where 70 is an approximate representation of the metal concentration found in this study. Under these terms, NFMs from MSG are routinely marketed for no more than 400 euros per ton.

Whether it is the company carrying out the LFM project or a specialised recycling company to deal with the NFMs is of little concern, the different fractions can still be separated and valorised and the sum remunerated may at times even increase two or three-fold. Under this optimistic approach, Figure $8 \mathrm{a}, 8 \mathrm{~b}$ and 9 summarise the results of the seven marketable scraps in terms of proportion detected, contribution of each fraction ( $<90 \mathrm{~mm}$ and $\geq 90 \mathrm{~mm}$ ) and metal concentration, respectively.

\section{Al scrap}

As stated previously, $\mathrm{Al}$ is the most commonly detected $\mathrm{NFM}$, with Al pieces frequently containing Mg, Mn, Si, Fe, 


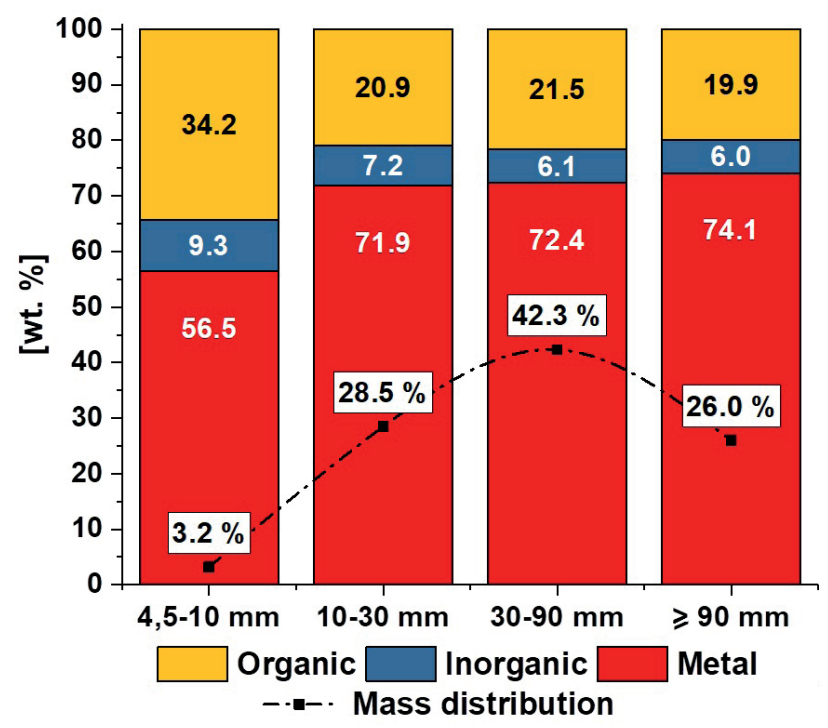

FIGURE 7: Concentration of metal and defilements in NFMs according to particle size [wt\%].

and $\mathrm{Cu}$ as alloying. The type and amount of alloying in the metal composition is related to the origin of the scraps. Al scraps in the fraction $<90 \mathrm{~mm}$ originate largely from packaging and foils, in which the metals have a negligible alloying content. On the other hand, the coarse fraction $(\geq 90$ $\mathrm{mm}$ ) contains particles of Al with a wide range of alloying and metallic pieces such as mechanically assembled screws. The characterisation assay performed revealed that the coarse fraction also contained a small proportion of Al packaging and foils. It is important to highlight that $\mathrm{Al}$ foils in the coarse fraction were found bound to other materials which had initially been absent. Al packaging detected in the coarse fractions was seven to eight-fold lower than in the fines (see the category Al-pack in Figures 4a and 4b).

As shown in Figure 7, the fraction 4.5-10 mm contained the most significant number of impurities; accordingly, Al was retrieved together with other metals such as $\mathrm{Zn}, \mathrm{Pb}$ or $\mathrm{Cu}$. The fractions $10-30 \mathrm{~mm}$ and $30-90$ were made up largely of Al packaging and foils. During thermal treatment, defilements were removed almost entirely; these two fractions therefore are expected to produce a relatively highgrade aluminium during refining.

Although no studies have been conducted to date to investigate the obtaining of Al from LFW, experience gained with MSW indicates the possibility of using dense media separators and XRT sorting technology to separate Al from other NFMs (Capuzzi and Timelli, 2018; Lucas et al., 2019; Schmitz et al., 2006).

Irrespective of whether or not the $<10 \mathrm{~mm}$ and $>90 / 100$ $\mathrm{mm}$ fractions are separated by screening, a scrap similar to UBC may be produced from the total fraction of Al scrap (see Figure 8b). UBC scrap is traded as TAKE, TALC or TALCRED (Scrap Specifications Circular, 2017); in Europe, the going rate on the scrap market is up to 1,400 euros per ton (Table 5). These potentially high-grade Al scraps from LFW, known as Al-scrap I, represent 26.4 wt\% of NFMs (Figure 7a) and, as shown in Figure $8 b$, are made up almost totally of Al from the fine fraction $(<90 \mathrm{~mm})$. In line with the results presented in Figure 9, 70.7 wt\% of this scrap can be valorised, with the potential price of Al-scrap I with defilements being in the range of 990 euros per ton.

On the scrap market, the price for Al foils may reach up to 200 euros per ton (see TAINT/TABOR standard in Table 5), particularly as these foils are highly sensitive to oxidation during refining. According to Soo et al. (2019), the price of $\mathrm{Al}$ with high Fe content is 1,000 euros per ton. The category Al-scrap II contains Al from the fraction below $10 \mathrm{~mm}$ (mainly Al foils mixed with other metals) and Al from the coarse fraction (Al alloys and Al with mechanically linked metals such as screws and nuts). Consequently, on considering the concentration of impurities (28 wt\%), the expected prices would drop to less than 500 euros per ton.

Al scraps are treated exclusively in the secondary production circuit (Bever, 1976) and, due to the presence of undesirable alloying elements in the scrap, are used in combination with primary Al to produce alloys for specific applications, for example, parts and engines for the car industry (Paraskevas et al., 2015). (a)

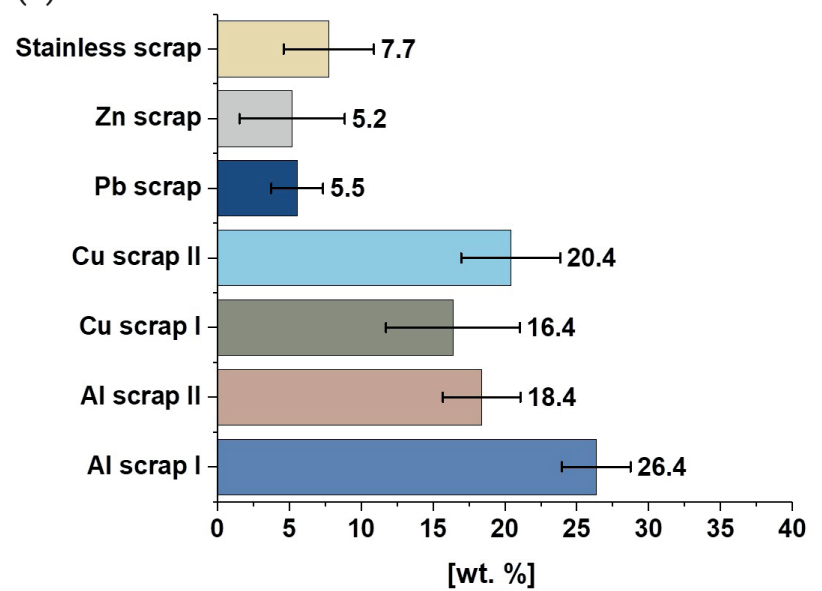

(b)

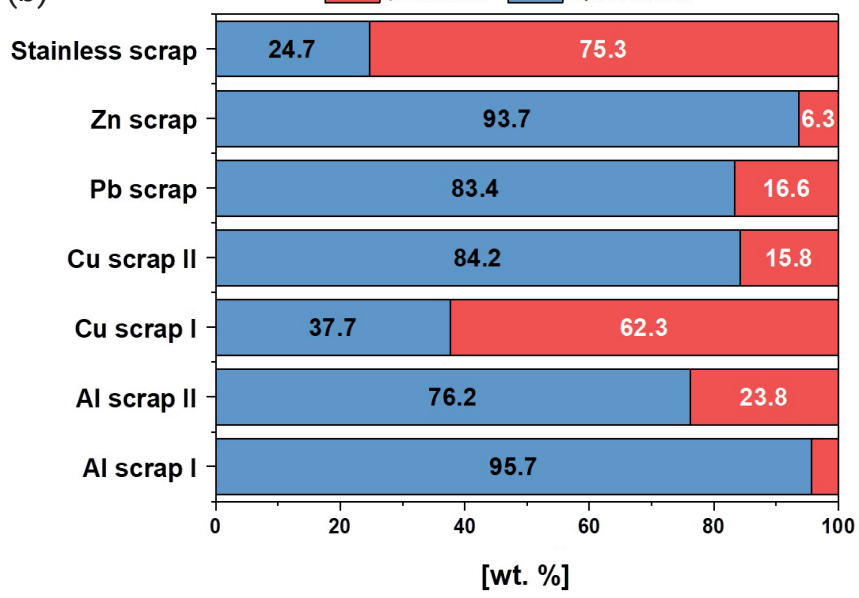

FIGURE 8: Type of marketable NFM scraps: (a) proportions (b) contribution of each fraction. 


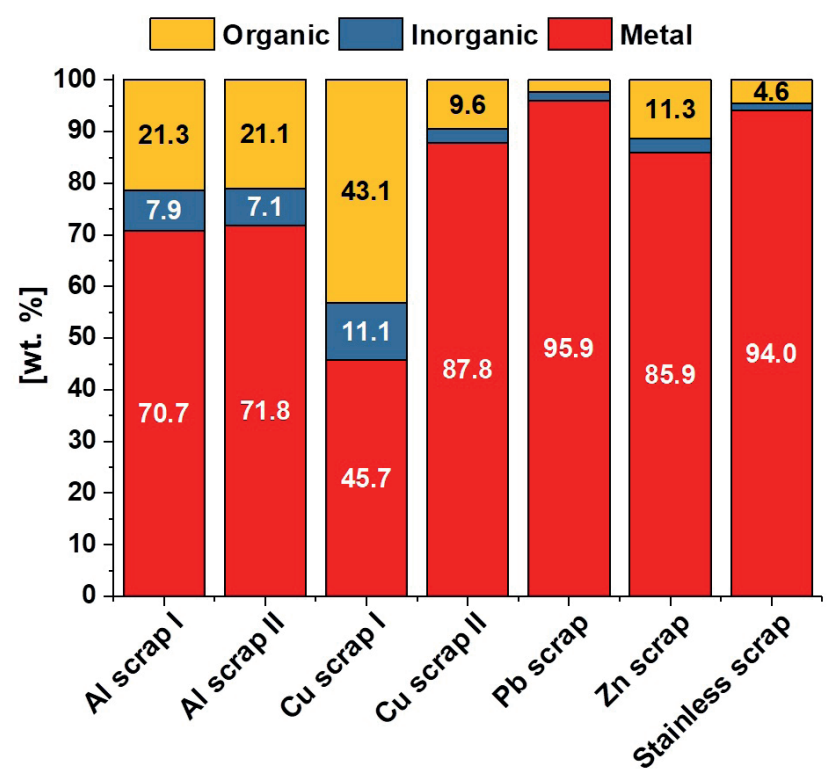

FIGURE 9: Concentration of metal and defilements in marketable NFMs [wt $]$.

\section{Cu scrap}

Cu scraps are the second most common type of NFM detected in the investigated fractions. The amount of $\mathrm{Cu}$ found was higher than expected due to the presence of C\&D and industrial waste. Two different $\mathrm{Cu}$ scraps complying to a large extent with market standards were identified; $\mathrm{Cu}$ scrap I obtained entirely from the category Cu-wires, and Cu-scrap II containing metals from the categories Brass and Other metals. Sorting technologies or dense-media separators may be used to separate wires from other $\mathrm{Cu}$ scraps. Almost $55 \mathrm{wt} \%$ of $\mathrm{Cu}$ wires are non-metallic (Fig. ure 8), therefore featuring a low relative density compared to other heavy NFMs (lead, zinc, stainless steel and brass).

The purity of $\mathrm{Cu}$ in wires usually exceeds $96 \%$ and can be sold on the scrap market in the Droid category (Insulated Cu wire scrap N ${ }^{\circ} 2$ ). The standard applied for Droid normally stipulates a metal concentration of $45 \%$, similar to the trends observed in this study (Figure 9); rates currently offered per ton are in the range of 1,100 euros (see Table 5). Providing a chopping process (Schlesinger et al., 2011) is carried out, the metal obtained may reach prices of 3,250 euros per ton under the Birch standard.

Cu-scrap II contains $63 \mathrm{wt} \%$ of $\mathrm{Cu}$, in addition to a series of other alloying materials and impurities such as $\mathrm{Zn}, \mathrm{Pb}$, $\mathrm{Ni}, \mathrm{Sn}, \mathrm{Fe}, \mathrm{Ag}$ and $\mathrm{Zn}$, with its alloys also being included in this category. This topic will be discussed further below in "Zn and $\mathrm{Pb}$ scrap". Accordingly, Cu-scrap II, consisting of a mixture of heavy NFMs, reaches requirements for the standard Zebra or Heavy brass (Table 5). This category features only 12. wt\% defilements (Figure 9) and is marketed at 2,400 euros per ton.

Indeed, Cu-scrap I is valorised by undergoing a chopping process in either the primary or secondary Cu production circuit during the first or second refining stage to produce "Anode-copper". Potential applications for Cu-scrap II include use in a matte smelter or converter furnaces, which use scraps having a Cu concentration of less than $80 \%$ ( $\mathrm{Ha}-$ bashi, 1998; Schlesinger et al., 2011).

\section{$\mathrm{Pb}$ and $\mathrm{Zn}$ scrap}

$\mathrm{Pb}$-scrap represents approx. $5.5 \mathrm{wt} \%$ of all NFMs identified (Figure 8a) and, as shown in Figure 8b, is found mainly in the fraction $<90 \mathrm{~mm}$. Analysed $\mathrm{Pb}$ pieces featured the presence of less than 5\% defilements (Figure 9), indicating the suitability of these scraps for direct marketing as "mixed Pb scrap" or "Pb scrap" (Table 5). The current rate for $\mathrm{Pb}$ scrap, separated from NFMs by means of sorting technologies, is up to 1,000 euros per ton.

The scraps undergo treatment in the secondary $\mathrm{Pb}$ industry initially via pyrometallurgical treatment and subsequently electro-refining in the same way as $\mathrm{Cu}$ (Habashi, 1998).

Zn-scrap is tradable as Score (Scrap Specifications Circular, 2017) with a marked price of 600 euros per ton. However, only $\mathrm{Zn}$ scraps from the coarse fraction can potentially be separated using sorting technologies in view of the relatively high purity. The recovery of $\mathrm{Zn}$ from fine fractions is complex, being frequently bound to other metals and polymers. Cu-scrap II contains $\mathrm{Zn}$ as the main alloy, and during the refining of $\mathrm{Cu}, \mathrm{Zn}$ oxide is recovered from the off-gas of converter furnaces. The latter might therefore also be included as Cu-scrap II.

\section{Old stainless steel scrap}

Approximately $75 \%$ of stainless steel scraps originating largely from C\&D or industrial waste were recovered from the coarse fraction. In terms of chemical composition, more than $85 \mathrm{wt} \%$ of the stainless steel recovered was AISI 304 or 316 (austenitic stainless steel). The steel industry is extremely severe with regard to the nature of pre-existing alloying elements in these scraps, indicating the need to apply sorting technologies to separate the scraps into different stainless steel categories. On separation from other NFMs, austenitic scrap is traded under the ISRI code Sabot (Scrap Specifications Circular, 2017), with a market price of 720 euros per ton (Table 5).

Table 7 summarises calculation of the feasible price ranges for all NFMs, including defilements.

\section{DISCUSSION}

Prior to the advent of thermal treatment, separation (i.e. cleaning) of organic matter and soil from the surface of the metal was an arduous task. The majority of the metals had been buried, pressed and compacted under the weight of overlying waste for a period of 40 to 60 years. During this time, defilements had frequently become strongly bound to the metals. Accordingly, when assessing the quality of metal retrieved from landfills, studies conducted to investigate the effect generated during anaerobic and humic phases (Belevi and Baccini, 1989; Bozkurt, 1998; Bozkurt et al., 1999; Martensson et al., 1999) should be given due consideration. During the anaerobic phase, metals are affected by corrosion due to the presence of organic acids. The anaerobic phase is followed by slow mineralisation of organic matter, which might explain the difficulties encountered when cleaning the metals. 
TABLE 7: Calculated potential prices of NFMs recovered from MSG.

\begin{tabular}{|c|c|c|c|c|}
\hline Category & Proportion [wt\%] & Potential Price [euro/ton] & ISRI code & Details \\
\hline \multicolumn{5}{|l|}{ Realistic approach } \\
\hline NFM & 100 & 400 & Zorba70 & $\begin{array}{l}\text { Mixed nonferrous scrap with a metal con- } \\
\text { centration of } 70 \%\end{array}$ \\
\hline Total & \multicolumn{4}{|l|}{400 euros per ton } \\
\hline \multicolumn{5}{|l|}{ Optimistic approach } \\
\hline \multicolumn{5}{|l|}{ Al-scrap } \\
\hline Al-scrap I & 26.4 & 900 & TAKE, TALC or TALCRED & UBC with a small amount of Al-foils \\
\hline Al-scrap II & 18.4 & 500 & NA & $\begin{array}{l}\text { Mixture of Al-foils priced at } 200 \text { euros per } \\
\text { ton and Al polluted with Fe scrap with a price } \\
\text { of } 1000 \text { euros per ton (Soo et al. (2019) }\end{array}$ \\
\hline \multicolumn{5}{|l|}{ Cu-scrap } \\
\hline Cu-scrap I & 16.4 & 1,100 & Droid & $\begin{array}{l}\text { Insulated Cu wire scrap N No2 (metal purity } \\
>96 \% \text { ) }\end{array}$ \\
\hline Cu-scrap II & 20.4 & 2,400 & Zebra & Mixed heavy nonferrous metals \\
\hline Pb-scrap & 5.5 & 1,000 & NA & $\begin{array}{l}\text { mixed lead scrap does not have an ISRI } \\
\text { code, but is commercialised as is. }\end{array}$ \\
\hline Zn-scrap & 5.2 & 600 & Score & Zn scrap from the coarse fractions \\
\hline Stainless steel scrap & 7.7 & 720 & Sabot & Austenitic stainless steel scraps \\
\hline Total & \multicolumn{4}{|l|}{$1,141.24$ euros per ton } \\
\hline
\end{tabular}

In spite of a large number of surface defilements attached to these scraps, the majority of NFMs show no severe signs of deterioration compared with ferrous scraps, not included in this study. Nevertheless, some Cu alloys and all steel-tin cans analysed showed clear signs of deterioration.

The use of mobile technology is mandatory in the context of LFM projects in order to process LFW in situ. For this purpose, magnetic separators and ECSs are used in combination with other equipment such as ballistic separators and shredders to extract metals and other materials.

The use of more sophisticated in-situ technologies to separate scraps into different types should be evaluated in terms of cost and potential benefits to be obtained. Realistically however, in an LFM project, "mixed nonferrous scrap" alone is retrieved and traded direct from the landfill.

An intermediate approach aimed at separating NFMs into a light fraction (composed mostly of aluminium) and a heavy fraction employing dense media separators in situ may also be conceivable. Should this be the case, the prices paid will be intermediate, ranging from 500 to 700 euros per ton.

\section{CONCLUSIONS}

Preliminary results obtained by means of mechanical and manual processing revealed a concentration of NFMs corresponding to $4.8 \mathrm{~kg}$ per ton of LFW. Defilements however amounted to $27.3 \mathrm{wt} \%$, thus, the actual amount of recoverable NFMs wass closer to $3.5 \mathrm{~kg}$ per ton.

Application of a thermal process following the guidelines issued by the Al industry for de-coating treatments proved useful in eliminating and separating the majority of defilements from NFMs in a raw state. It should however be highlighted that prior to incineration metal scraps should be separated according to metal categories, e.g. Al, $\mathrm{Cu}, \mathrm{Pb}, \mathrm{Zn}$ and stainless steel.
The steel and Al industries are extremely severe in relation to the pollutants and alloying content of scraps. Accordingly, these two metals will need to be subjected to particular care in separation and assessment; the use of sorting technologies such as those based on XRF and XRT sensors is recommended.

The $\mathrm{Cu}$ industry is marginally flexible with regard to the type of defilements and metals mixed with Cu scraps in view of the possibility of their re-use in a wide range of processes in both primary and secondary circuits. Primary production circuits apply stricter limitations for pollutants and alloying content, dependent on whether these scraps enter into the first or second refining steps; however, less severe constraints are applied if the scraps are used in matte smelters.

The current rates paid in the commercialisation of NFMs may vary from 400 euros for a mixed-nonferrous scrap to more than 1,100 euros per ton for NFMs that have been separated and divided by categories and grades. To conclude therefore, appropriate technical and economic assessment should be undertaken with the aim of determining the most suitable strategy in order to maximise profitability of the recovered scraps.

\section{ACKNOWLEDGEMENTS}

This project was funded by a grant awarded by the EU Framework Programme for Research and Innovation H2020 under Grant Agreement No 721185 (NEW-MINE; https://new-mine.eu/).

\section{REFERENCES}

Abdalla, A.N., Faraj, M.A., Samsuri, F., Rifai, D., Ali, K., Al-Douri, Y., 2019. Challenges in improving the performance of eddy current testing: Review. Meas. Control 52, 46-64. https://doi. org/10.1177/0020294018801382 
Barker, K., 2014. Dense Medium Separation Ideal for Processing SR and Zorba [WWW Document]. Recycl. Prod. News. URL https://www. recyclingproductnews.com/article/19742/dense-medium-separation-ideal-for-processing-sr-and-zorba (accessed 6.25.19).

Belevi, H., Baccini, P., 1989. Long-term behavior of municipal solid waste landfills. Waste Manag. Res. 7, 43-56. https://doi. org/10.1016/0734-242X(89)90007-4

Bozkurt, S., 1998. Simulations of the long-term chemical evolution in waste deposits (Licentiate Thesis). Department of Chemical Engineering and Technology, Royal Institute of Technology, Sweden.

Bozkurt, S., Moreno, L., Neretnieks, I., 1999. Long-term fate of organics in waste deposits and its effect on metal release. Sci. Total Environ. 228, 135-152. https://doi.org/10.1016/S0048-9697(99)00047-9

Capuzzi, S., Timelli, G., 2018. Preparation and Melting of Scrap in Aluminum Recycling: A Review. Metals 8, 249. https://doi.org/10.3390/ met8040249

Cohen-Rosenthal, E., 2004. Making sense out of industrial ecology: a framework for analysis and action. Appl. Ind. Ecol. 12, 1111-1123. https://doi.org/10.1016/j.jclepro.2004.02.009

Dürkoop, A., Brandstetter, CP., Gräbe, G., Rentsch, L., 2016. Innovative Technologien für Ressourceneffizienz - Strategische Metalle und Mineralien $\left(r^{3}\right)$. Germany.

García López, C., Pretz, T., Hernández Parrodi, J.C., Küppers, B., Ni, A., 2018. Characterization of landfill mining material after ballistic separation to evaluate material and energy recovery. Detritus. https://doi.org/10.31025/2611-4135/2019.13780

Habashi, F. (Ed.), 1998. Handbook of Extractive Metallurgy. Wiley-VCH, Weinheim; New York.

Hernández Parrodi, J.C., Garcia Lopez, C., Küppers, B., Raulf, K., Vollprecht, D., Pretz, T., Pomberger, R., 2019. Case study on enhanced landfill mining at Mont-Saint-Guibert landfill in Belgium: Characterization and potential of fine fractions. Detritus In Press.

Hernández Parrodi, J.C., Höllen, D., Pomberger, R., 2018. Potential and main technological challenges for material and energy recovery from fine fraction of landfilll mining: A critical review. Detritus In Press, 1. https://doi.org/10.31025/2611-4135/2018.13689

Hernandez Parrodi, J.C., Raulf, K., Vollprecht, D., Pomberger, R., 2019. Mechanical processing of fine fractions from landfill mining for material and energy recovery. Presented at the 17th International waste management and landfill symposium, Sardinia, Italy, p. Submitted.

IGRETEC, 1994. Etudie des incidences sur l'environnement. ISSeP, Belgium.

ISSeP, 2011. Historique de l'exploitation depuis 1937 [History of operation since 1937] (No. Réf. ISSeP - C.E.T. - MSG-exp04 historique). C.E.T. de Mont-Saint-Guibert, MSG, Belgium.

Kapur, A., Graedel, T.E., 2006. Copper mines above and below the ground. Estimating the stocks of materials in ore, products, and disposal sites opens up new ways to recycle and reuse valuable resources. Environ. Sci. Technol. 40, 3135-3141.

Krook, J., Svensson, N., Eklund, M., 2012. Landfill mining: A critical review of two decades of research. Waste Manag. 32, 513-520. https://doi.org/10.1016/j.wasman.2011.10.015

Lifset, R.J., Gordon, R.B., Graedel, T.E., Spatari, S., Bertram, M., 2002. Where has all the copper gone: The stocks and flows project, part 1. JOM 54, 21-26. https://doi.org/10.1007/BF02709216
Lucas, H., Li, C., Hernandez Parrodi, J.C., Garcia Lopez, C., Gursel, D., Friedrich, B., Pretz, T., Wotruba, H., 2019. Primary evaluation of the use and refining of $\mathrm{Al}$ scrap recovered from a landfill in Belgium. Presented at the EMC, Dusseldorf, Germany, pp. 51-61.

Martensson, A.M., Aulin, C., Wahlberg, O., Agren, S., 1999. Effect of humic substances on the mobility of toxic metals in a mature landfill. Waste Manag. Res. 17, 296-304. https://doi.org/10.1034/j.13993070.1999.00053.x

Morf, L.S., Gloor, R., Haag, O., Haupt, M., Skutan, S., Lorenzo, F.D., Böni, D., 2013. Precious metals and rare earth elements in municipal solid waste - Sources and fate in a Swiss incineration plant. Waste Manag. 33, 634-644. https://doi.org/10.1016/j.wasman.2012.09.010

Muller, D.B., Wang, T., Duval, B., Graedel, T.E., 2006. Exploring the engine of anthropogenic iron cycles. Proc. Natl. Acad. Sci. 103, 1611116116. https://doi.org/10.1073/pnas.0603375103

Quaghebeur, M., Laenen, B., Geysen, D., Nielsen, P., Pontikes, Y., Van Gerven, T., Spooren, J., 2013. Characterization of landfilled materials: screening of the enhanced landfill mining potential. Spec. Vol. Urban Landfill Min. 55, 72-83. https://doi.org/10.1016/j.jclepro.2012.06.012

Samuel, M., 2003. A new technique for recycling aluminium scrap. J. Mater. Process. Technol. 135, 117-124. https://doi.org/10.1016/ S0924-0136(02)01133-0

Schlesinger, M.E., 2013. Aluminum Recycling, 0 ed. CRC Press. https:// doi.org/10.1201/b16192

Schlesinger, M.E., King, M.J., Sole, K.C., Davenport, W.G., 2011. Collection and Processing of Recycled Copper, in Extractive Metallurgy of Copper. Elsevier, pp. 373-387. https://doi.org/10.1016/B978-008-096789-9.10018-6

Schmitz, C. (Ed.), 2006. Part Mechanical Preparation: Process lines for mechanical preparation, in Handbook of Aluminium Recycling: Mechanical Preparation, Metallurgical Processing, Heat Treatment. Vulkan-Verlag GmbH, Essen, pp. 56-71.

Schmitz, C., Domagala, J., Haag, P. (Eds.), 2006. Handbook of aluminium recycling. Vulkan, Essen.

Scrap Specifications Circular, 2017. . ISRI, USA

Soo, V.K., Peeters, J.R., Compston, P., Doolan, M., Duflou, J.R., 2019. Economic and Environmental Evaluation of Aluminium Recycling based on a Belgian Case Study. Procedia Manuf. 33, 639-646. https://doi.org/10.1016/j.promfg.2019.04.080

Spencer, D.B., Schlömann, E., 1975. Recovery of non-ferrous metals by means of permanent magnets. Resour. Recovery Conserv. 1 , 151-165. https://doi.org/10.1016/0304-3967(75)90022-0

Van Vossen, W.J., Prent, O.J., 2011. Feasibility study: Sustainable material and energy recovery from landfills in Europe., in Proceedings Sardinia 2011. Presented at the Thirteen International Waste Management and Landfill Symposium, Sardinia, Italy, pp. 247-248.

Winterstetter, A., Laner, D., Rechberger, H., Fellner, J., 2015. Framework for the evaluation of anthropogenic resources: A landfill mining case study - Resource or reserve? Resour. Conserv. Recycl. 96, 19-30. https://doi.org/10.1016/j.resconrec.2015.01.004

Wolfsberger, T., Sarc, R., Pomberger, R., 2015. Quality and recovery of specific waste fractions from Landfill Mining for material and energy recovery. Presented at the International Landfill Mining Conference, Grece.

XIAO, Y., REUTER, M.A., BOIN, U., 2005. Aluminium Recycling and Environmental Issues of Salt Slag Treatment. J. Environ. Sci. Health Part A 40, 1861-1875. https://doi.org/10.1080/10934520500183824 